\title{
CARPAL TUNNEL SYNDROME AS A MANIFESTATION OF SYSTEMIC DISEASE
}

BY

\author{
R. S. PHILLIPS \\ Department of Orthopaedic Surgery, Royal Infirmary, Manchester
}

The syndrome of compression of the median nerve in the carpal tunnel produces well-defined symptoms and signs. Often there is electromyographic evidence of impaired neural conduction at the level of the wrist. The clinical features of the syndrome have been described clearly by Garland, Bradshaw, and Clark (1957) and by Phalen and Kendrick (1957).

To appreciate the many aetiological factors which have been incriminated in the causation of the syndrome, an accurate knowledge of the anatomy of the volar aspect of the wrist is required. Robbins (1963) has prepared transverse and longitudinal sections of the cadaveric hand and wrist to display the unyielding boundaries of the carpal tunnel. The relationship of the median nerve to the flexor tendons as they traverse the tunnel are depicted clearly. There is considerable crowding of the structures that lie within the tunnel. Any decrease in its size or increase in the volume of its contents is reflected in alteration of function in the most susceptible structure, the median nerve.

Many traumatic disorders have been incriminated in the aetiology of this syndrome of median nerve compression. These include recent and healed Colles' fractures (Lynch and Lipscomb, 1963), dislocation of the lunate bone, and degenerative arthritis of the radio-carpal or intercarpal joints (Robbins, 1963). Of the non-traumatic causes, tumours (e.g. ganglion, lipoma) are not uncommon; primary amyloidosis (Grokoest and Demartini, 1954) and myeloma (Rubio, 1960) are rare causes. Tophaceous gout and rheumatoid and non-specific tenosynovitis have been found associated with the syndrome (Grossman, Kaplan, Ownby, and Grossman, 1961), often in their early stages. Myxoedema and acromegaly, presumably because of alterations in soft tissue metabolism, have produced carpal tunnel syndrome (Johnston, 1960; Skanse, 1961). The fluid retention of pregnancy may also account for the increased incidence of the syndrome in that condition (Heathfield and Tibbles, 1961).

At operation, the median nerve, in addition to flattening within the carpal tunnel, may manifest proximal thickening or its sheath may appear hypertrophied. These pathological features are more likely to be the effect than the cause of nerve compression.

Although numerous pathological and functional disorders have been described in association with the carpal tunnel syndrome, not in every case can a predisposing factor be elicited. It is recognized that the syndrome can be part of a generalized systemic disorder when such a condition has already manifested itself in other ways. The object of the present investigation is to assess the long-term results of operation for decompression of the median nerve at the wrist, to discover if the syndrome is a prodromal or early phase of a generalized disorder, and to ascertain if there is an association between the syndrome and any degenerative or inflammatory skeletal or soft tissue disease.

\section{Method and Material}

Series.-In a group of 54 patients (11 men and 43 women), unselected other than that they received operative treatment for median nerve compression at the wrist, symptoms and signs were recorded from case notes and radiographs at the time of operation, not only of the carpal tunnel syndrome but also of any associated or related disorder of mesodermal tissue, viz. osteoarthritis, cervical spondylosis, rheumatoid disease, gout, etc. Any local or generalized condition which, from present knowledge, might have been involved in the production of the syndrome was noted.

All those who underwent surgery had had a simple division of the flexor retinaculum at the wrist performed under brachial block or general anaesthesia. In nine patients the procedure was undertaken first on one wrist and then on the other at a later date.

In the whole series, 36 patients had the right hand 
operated upon and only nine the left hand. Both sides were operated on in a further nine patients, but seven of these had symptoms first, or more severely, in the right hand. The question of the relationship of the dominant hand to the incidence of the syndrome is discussed below.

Follow-up.-An assessment, at least 5 years after operation, of these patients included a history and physical examination of the affected wrist, the spine, and all major joints, and an inquiry regarding the development of any disease and its treatment in the period between operation and follow-up.

Radiographs of the hands, wrists, and cervical spine were done routinely, and when indicated clinically, haematological, biochemical, and immunological investigations were carried out.

Of the original 54 patients, eleven were not traced or refused re-examination, and two died from unrelated causes (carcinoma of the breast and cerebral thrombosis). Thus 41 patients (five men and 36 women) were reviewed; their average age at the time of this review was 53 years and the mean length of follow-up was 7 years 9 months.

\section{Results}

Of the 41 patients who reported for review, 31 had no symptoms in reference to median nerve compression, nine still had minimal symptoms and signs amounting to no more than a mere intermittent nuisance to the individual and only one had recurrent or persistent symptoms of moderate severity. Six patients, however, had developed symptoms of a minimal nature in the unoperated hand and wrist.

None of the 41 patients reviewed had clinical or histological evidence of rheumatoid tenosynovitis of the flexor tendons in the carpal tunnel, although a mild, chronic, non-specific tenosynovitis was present in five of them. In six of the 41 patients reviewed, local lesions involving the carpal bones or distal radius could, with reasonable suspicion, be included in the syndrome of median nerve compression. Four of the six had sustained a Colles' fracture or undisplaced fracture of the radial styloid in the year preceding the appearance of nerve compression symptoms; the other two had clinical or radiological signs of osteo-arthritis of the radio-carpal joint.

If, therefore, one excludes the six patients with a local lesion at the wrist but includes the five who had a non-specific tenosynovitis, there were 35 patients ( 32 women and 3 men) in whom no local or generalized disorder could be incriminated in the pathogenesis of the syndrome. It is this group which has been studied from the aspect of associated generalized disease.

Pre-operative Findings.-From the original notes and radiographs, it was found that 15 of the 35 (43 per cent.) had shown evidence of degenerative disease of the cervical intervertebral disks. This condition was accepted as being present when two or more disk spaces were narrowed and osteophytes were visible on the anterior margins of the involved vertebrae.

The syndrome of primary generalized osteoarthritis has been described clearly by Kellgren and Moore (1952) and its clinical features need no elaboration here. There was evidence of the established syndrome, i.e. involvement of three joints or more, in five of the 35 patients (14 per cent.). In only one was there definite clinical evidence of generalized rheumatoid arthritis.

Follow-up.-When the series was reviewed postoperatively, $26(74 \cdot 3$ per cent.) displayed cervical spondylosis, seventeen ( 48.6 per cent.) had radiological evidence of generalized osteo-arthritis with involvement of three joints or more, and three (8.6 per cent) had clinical rheumatoid arthritis; in none of the last was there any serological confirmation as shown by the differential agglutination test or elevation of the erythrocyte sedimentation rate.

Six patients, all female, of those reviewed had had a trigger finger operated upon, either before or after surgery for compression of the median nerve in the same limb. This incidence (17 per cent.) seems to imply a significant association with the nerve compression syndrome, although no figures are available on the incidence of trigger finger among the general population.

Table I shows the incidence of generalized disease, but for ease of statistical study the three male patients in the group are excluded from the following discussion.

TABLE I

GENERALIZED DISEASE IN 32 FEMALES AND 3 MALES BEFORE OPERATION AND AT FOLLOW-UP

\begin{tabular}{|c|c|c|c|c|c|c|c|c|}
\hline \multirow[t]{2}{*}{$\begin{array}{c}\text { Time of } \\
\text { Assessment }\end{array}$} & \multirow[t]{2}{*}{ Sex } & \multirow[t]{2}{*}{ No. of Cases } & \multicolumn{2}{|c|}{ Cervical Spondylosis } & \multicolumn{2}{|c|}{ Rheumatoid Arthritis } & \multicolumn{2}{|c|}{$\begin{array}{l}\text { Generalized } \\
\text { Osteo-arthritis }\end{array}$} \\
\hline & & & No. & Per cent. & No. & Per cent. & No. & Per cent. \\
\hline \multirow[t]{2}{*}{ Pre-operative } & $\mathbf{F}$ & 32 & 14 & 44 & 1 & 3 & 5 & 16 \\
\hline & $\mathbf{M}$ & 3 & 1 & - & 0 & - & 0 & - \\
\hline \multirow[t]{2}{*}{ At Follow-up } & $\mathbf{F}$ & 32 & 24 & 75 & 3 & 10 & 16 & 50 \\
\hline & $\mathbf{M}$ & 3 & 2 & - & 0 & - & 1 & - \\
\hline
\end{tabular}




\section{Discussion}

Disk Degeneration.-Lawrence, de Graaff and Laine (1963) have studied degenerative joint disease in population samples in the urban and rural districts of Leigh and Wensleydale respectively. In a group of female patients, aged 45 to 74 years, they found cervical disk degeneration of moderate severity in 62 per cent.

In the present series, the incidence was 44 per cent. pre-operatively and 75 per cent. on review. Although the numbers involved were small, a statistical comparison has been made. When the pre-operative incidence of 44 per cent. is compared with the population sample, using the $\mathrm{X}^{2}$ test, $\mathrm{P}$ is greater than $0 \cdot 10$, and the difference is, therefore, unlikely to be significant. Applying the same statistical test in comparing the incidence on review of 75 per cent. with the population sample, $\mathbf{P}$ is greater than 0.05-unlikely to be significant. However, these tests of significance must be interpreted with care, because the mean age of the series is rather less than that of the population sample pre-operatively, and rather greater at follow-up. It is, then, likely that there is no statistically significant difference in the incidence of cervical spondylosis between the series of median nerve compression patients and the random population sample.

Osteo-arthritis.-Kellgren, Lawrence, and Bier (1963), again in the Leigh and Wensleydale studies, have shown that in females over 45 years of age, 51 per cent. have primary generalized osteoarthritis involving three or more joints. In the present series, the incidence was 16 per cent. preoperatively and 50 per cent. on review. Again, the difficulties of statistical interpretation are stressed and again it is unlikely that primary generalized osteoarthritis and median nerve compression in the carpal tunnel are related.

Rheumatoid Arthritis.-The incidence of clinical rheumatoid arthritis has been thought to be as high as 15 per cent. in females (Lawrence and Ball, 1958), a figure which these authors believe to be artificially high due to the inclusion of similar syndromes, e.g. generalized osteo-arthritis. Although figures of 3 per cent. (one patient) and 9.4 per cent. (three patients) were noted pre-operatively and at review, our numbers are too small for valid comparison.

Sex and Dominant Hand.-Certain points in this series of patients with the carpal tunnel syndrome require further discussion. Of the whole series of 54 patients, 43 were female, and of the 41 reviewed, 36 were female. Further, in 45 unilateral operations, the right side was involved on 36 occasions, and in the nine bilateral procedures, the right side presented initially or with more severe symptoms on seven occasions.

The dominant hand of each patient was ascertained by means of a questionnaire and this information was then related to the side of operation (Table II). Of the 41 patients reviewed, all 29 who had been operated upon for symptoms in the right hand stated that this was their dominant hand. Similarly, all five bilateral cases who had the right hand more severely involved initially stated that this was the dominant hand. Of three left-handed patients in the series, one was a bilateral case in which the left hand was initially the more troublesome and the other two had been operated upon for symptoms in the left hand.

TABLE II

SIDE OF OPERATION AND DOMINANT HAND IN 41 PATIENTS REVIEWED

\begin{tabular}{|c|c|c|c|}
\hline & \multirow{2}{*}{ Operation } & \multicolumn{2}{|c|}{ Dominant Hand } \\
\hline & & Right & Left \\
\hline Unilateral & $\left.\begin{array}{r}29 \\
5\end{array}\right\} 34$ & $\begin{array}{r}29 \\
3\end{array}$ & $\begin{array}{l}0 \\
2\end{array}$ \\
\hline Bilateral & $\left.\begin{array}{l}\text { Right initially or more severe } 5 \\
\text { Left initially or more severe } 2\end{array}\right\} 7$ & $\begin{array}{l}5 \\
1\end{array}$ & $\begin{array}{l}0 \\
1\end{array}$ \\
\hline Total & 41 & 38 & 3 \\
\hline
\end{tabular}

Of the six patients in the series reviewed in whom traumatic causes could be incriminated, i.e. fracture or localized osteo-arthritis, all were right-handed and all had compression of the right median nerve.

Clearly then, in this series at least, this syndrome of compression of the median nerve in the carpal tunnel is most frequently found in the right wrists of right-handed women in the sixth decade of life. It may therefore be deduced that the syndrome is unlikely to be associated with the generalized degenerative disorders such as cervical spondylosis and primary generalized osteo-arthritis, because Lawrence and others (1963) and Kellgren and others (1963) found no statistically significant differential sex incidence in these two disorders. There is no doubt that rheumatoid arthritis is more common in women, but it does not selectively involve the right wrist and the sheaths of its overlying tendons.

That this syndrome of median nerve compression should occur mainly in menopausal women in the dominant hand merits explanation. Robbins (1963), in his anatomical studies of the carpal tunnel, makes no mention of any sex difference in either the boundaries or the contents of the tunnel. It seems logical to assume that because of the smaller bone structure in women the volume of the tunnel will be less than 
that of the male, but the volume of the traversing structures will be proportionally smaller. If there is, then, no anatomical difference between the sexes, there is certainly a hormonal one, since the syndrome occurs most frequently in the immediate post-menopausal years. The hormone, oestrogen, has farreaching effects. Wright (1952), discussing the role of the female sex hormones, stated that oestrogen inhibits the secretion of anterior pituitary hormones, and when this hormone is injected into experimental animals for long periods, the functions of the pituitary are often gravely deranged. After the menopause, then, it may be that the anterior pituitary escapes from the inhibiting effect of oestrogen with consequent increase in the circulation of its own secretions, particularly growth hormone. Other glandular disorders, e.g. acromegaly, are recognizably associated in the aetiology of the carpal tunnel syndrome (Skanse, 1961), so that the hypothesis of oestrogen withdrawal is plausible. The fact that symptoms of median nerve compression may start in pregnancy in no way detracts from the hypothesis, because it is thought that fluid retention in that condition is responsible for the nerve compression symptoms (Johnston, 1960; Heathfield and Tibbles, 1961).

Despite the lack of statistical confirmation, a 17 per cent. incidence of trigger finger in the ipsilateral limb cannot be ignored. The thickened flexor tendon sheath of the trigger finger displays, macroscopically at least, many features of the hypertrophied flexor retinaculum at the wrist. This similarity may be extended to postulate a common aetiology both hormonally and otherwise.

That it should be the dominant hand and wrist that is involved, at once suggests that repetitive minimal trauma, excessive use, and occupational factors may be responsible. The fact that, of six patients in the series who had a local traumatic lesion, i.e. fracture or localized osteo-arthritis, lends credence to the suggestion that repetitive trauma of a mild nature, particularly in the hand and wrist that takes the greater work load, may be concerned in the aetiology of the syndrome in the other patients in the series.

Robbins (1963) has shown that the volume of the carpal tunnel is reduced maximally in full flexion and extension of the wrist. There is no doubt that the busy housewife is constantly employed at some task which necessitates the use of her hands. Wringing, mixing, dusting, polishing, bed-making, all require a full range of wrist movements, often involving grasping and twisting. It may well be that her median nerve lesion is the outcome, in part at least, of her never-ending, but always repetitive, round of household chores.

\section{Summary}

Fifty-four patients having undergone surgery for median nerve compression at the wrist were reviewed post-operatively after an average of 7 years 9 months. Because of death, or other circumstances, only 41 were included in the complete study of the carpal tunnel syndrome as a manifestation of systemic disease.

Of these 41 patients, 36 were female, their average age being 53 years. In the whole series the right hand was involved alone or more severely on 43 occasions and the left on eleven. At the time of review 31 patients had no symptoms and only one had recurrent or persistent trouble of moderate severity.

In six patients, local disorders at the wrist could be incriminated aetiologically. The remaining 35 included three males who have been omitted from the statistical study. The incidence pre-operatively and on review of cervical spondylosis, generalized osteoarthritis, and rheumatoid arthritis in these 32 women was compared with the known incidence of these diseases in random samples of the general population. Statistically no difference was noted.

Trigger finger occurred in the ipsilateral limb in 17 per cent. of these women, but the incidence of this disorder in the general population is not known.

The predominant involvement of the dominant hand is thought to be of great significance. It is clearly important that the carpal tunnel syndrome is mainly a disorder of post-menopausal females (often with an associated trigger finger) and occurs most frequently in the dominant hand. The influence of oestrogen withdrawal, repetitive minimal trauma, and sexual variations in anatomy at the wrist are discussed.

I wish to thank Mr. D. Ll. Griffiths for his helpful criticisms in the compilation of this paper and for permission to study his patients.

\section{REFERENCES}

Garland, H., Bradshaw, J. P., and Clark, J. M. P. (1957). Brit. med. J., 1, 730 (Compression of the median nerve in the carpal tunnel and its relation to acroparaesthesia).

Grokoest, A. W., and Demartini, F. E. (1954). J. Amer. med. Ass., 155, 635 (Systemic disease and the carpal tunnel syndrome).

Grossman, L. A., Kaplan, H. J., Ownby, F. D., and Grossman, M. (1961). Ibid., 176, 259 (Carpal tunnel syndrome-the initial manifestation of systemic disease).

Heathfield, K. W. G., and Tibbles, J. A. R. (1961). Brit. med. J., 2, 29 (Chlorothiazide in carpal tunnel syndrome).

Johnston, A. W. (1960). Ibid., 1, 1616 (Acroparaesthesia and acromegaly). 
Kellgren, J. H., Lawrence, J. S., and Bier, F. (1963). Ann. rheum. Dis., 22, 237 (Genetic factors in generalized osteo-arthrosis).

— and Moore, R. (1952). Brit. med. J., 1, 181 (The syndrome of primary, generalized osteo-arthritis).

Lawrence, J. S., and Ball, J. (1958). Ann. rheum. Dis., 17, 160 (Genetic studies on rheumatoid arthritis). de Graaff, R., and Laine, V. A. I. (1963). In "Epidemiology of Chronic Rheumatism", a Symposium organized by the Council of International Organizations of Medical Sciences, ed. under direction of J. H. Kellgren, M. R. Jeffrey, and J. Ball, Rome, 1961, p. 98. Blackwell, Oxford.

Lynch, A. C., and Lipscomb, P. R. (1963). J. Amer. med. Ass., 185, 363 (Carpal tunnel syndrome and Colles' fractures).

Phalen, G. S., and Kendrick, J. I. (1957). Ibid., 164, 524 (Compression neuropathy of the median nerve in the carpal tunnel).

Robbins, H. (1963). J. Bone Jt Surg., 45A, 1953 (Anatomical study of the median nerve in the carpal tunnel and aetiologies of the carpal tunnel syndrome).

Rubio, F. (1960). J. Amer. med. Ass., 172, 476 (Carpal tunnel syndrome in myxoedema and acromegaly).

Skanse, B. (1961). Acta chir. scand., 121, 476 (Carpaltunnel syndrome in myxedema and acromegaly).

Wright, S. (1952). “Applied Physiology”, 9th ed., p. 1085. Oxford Medical Press, London.

\section{Le syndrome du canal carpien comme une manifestation} d'une maladie générale

\section{RÉSUMÉ}

On passe en revue, après une période moyenne de 7 ans et 9 mois, 54 cas de décompression chirurgicale du nerf médian au niveau du poignet. En raison du décès ou d'autres circonstances on n'inclut que 41 d'entre eux dans cette étude complète du syndrome du canal carpien comme manifestation d'une maladie générale.

Parmi ces 41 malades il y eut 36 femmes d'un âge moyen de 53 ans. Dans toute la série l'atteinte porta exclusivement ou plus sérieusement sur la main droite chez $\mathbf{4 3}$ malades et sur la main gauche chez 11 malades. Lors de la revue 31 malades n'accusaient pas de symptômes et un seul présentait un désordre récurrent ou persistant modérément sévère.

Chez six malades on pouvait incriminer étiologiquement des désordres locaux du poignet. Les 35 autres comprenaient trois hommes qui avaient été exclus de l'étude statistique. La fréquence avant l'opération et au moment de la revue de la spondylose cervicale, de l'ostéoarthrose généralisée et de l'arthrite rhumatismale parmi ces 32 femmes fut comparée avec celle dans la population générale, sans trouver de différence statistique.

On trouva le doigt à ressort dans la main atteinte en 17 pour cent de ces femmes, mais on ne connait pas la fréquence de ce désordre dans la population générale.

L'atteinte prééminente de la main dominante paraît très significative. Le fait que le syndrome du canal carpien survient surtout chez des femmes après la ménopause (souvent avec un doigt à ressort) et le plus souvent dans la main dominante est certainement important. A ce propos on discute l'influence de l'arrêt de la secrétion oestrogène, des traumatismes minimes mais répétés et des variations anatomiques du poignet selon le sexe.

\section{El sindrome del canal del carpo como manifestación de una enfermedad general}

\section{SUMario}

Después de un promedio postoperativo de 7 años y 9 meses se revisaron 54 casos de decompresión quirúrgica del nervio mediano en la muñeca. Por causa de muerte $\mathrm{u}$ otras otras circunstancias sólo 41 casos fueron incluídos en este estudio completo del síndrome del canal del carpo como manifestación de una enfermedad general.

De estos 41 casos 36 fueron mujeres de una edad media de 53 años. En la serie entera la mano derecha estaba comprometida exclusiva o más severamente en 43 casos y la izquierda en 11 casos. Al tiempo de revisión 31 enfermos no acusaban síntomas y sólo un caso presentaba signos de recurrencia o molestias contínuas de intensidad moderada.

En seis casos se pudieron incriminar alteraciones locales de la muñeca como etiología. Los 35 restantes incluían tres varones que habían sido excluidos del estudio estadístico. La incidencia antes de la operación y al tiempo de la revisión de la espondilosis cervical, osteoartrosis generalizada y artritis reumatoide en estas 32 mujeres fué comparada con la incidencia conocida en la población general de dichas enfermedades sin hallar diferencia estadística.

El dedo en gatillo en la mano afecta ocurrió en el $\mathbf{1 7}$ por ciento de estas mujeres, pero no se conoce la incidencia de esta lesión en la población.

La gran frecuencia de la lesión en la mano dominante parece muy significativa. El hecho de que el síndrome del canal del carpo se presente principalmente en mujeres postmenopáusicas (frecuentemente asociado con un dedo en gatillo) y en la mano dominante es claramente importante. En este respecto se discute la influencia de la interrupción de la secreción estrógena, de mínimos y repetidos traumas y de variaciones anatómicas en la muñeca según el sexo. 